\title{
EFFECT OF ELECTRICAL STUNNING ON QUALITY OF BROILER CARCASSES
}

\author{
SHAFIK S. ${ }^{1}$; EMAN SHUKRY ${ }^{1}$ AND KHEDER Z.A. ${ }^{2}$ \\ ${ }^{1}$ Department of Food Hygiene, Animal Health Research Institute, Mansoura lab \\ ${ }^{2}$ Department of Biochemistry, Nutritional deficiency and toxicology, Animal Health Research \\ Institute, Mansoura lab
}

Received: 30 December 2020; Accepted: 20 February 2021

\begin{abstract}
This study aimed to evaluate the effect of electrical stunning on quality of broiler carcasses. Two hundred of apparently healthy broiler Ross 208, $2 \mathrm{~kg}$ weight, 37 old day from the same flock were divided into two groups, each group of 100 broiler; the first on slaughtered without stunning while the second one was stunned in water bath stunner at 40 voltage for 10 seconds voltage. The results of this study showed that the sensory evaluation including color, texture, appearance, odor and general acceptance were 7, 6, 5, 7, and 6 in non- stunned carcasses while in stunned one they were $8,8,7,7$, and 7,5, respectively. The mean total bacterial counts were $4.3 \times 10^{5} \pm 1.07 \times 10^{5}$ in non stunned carcasses and $3.30 \times 10^{5} \pm 1.01 \times 10^{5}$ in stunned carcasses. The good effect of electrical stunning were occurred in carcasses quality because of grade $\mathrm{B}$ carcasses were decreased from $15 \%$ in non- stunned to $8 \%$ in stunned carcasses due to decrease of defects of brocken bone, red wing, wing bleeding spots, from $5 \%, 4 \%$ and, $4 \%$ in non stunned carcasses to $1 \%, 0 \%$ and $1 \%$ in stunned on although increase of breast bleeding spots from $2 \%$ in no stunned carcasses to $6 \%$ in stunned one. There is no detectable effect for low voltage water bath electrical stunning on chemical composition of meat (moisture, fat, protein and ash) with increase of $\mathrm{pH}$. In-addition to non-significant increase in anti-oxidants enzymes of slaughtered carcasses. From these study results, we recommend using the electrical stunning before broiler slaughter as it improves the carcasses quality through decreasing the manufacture defects as broken boned and not affects the chemical composition of carcasses meat.
\end{abstract}

Keywords: Electric - stunning - broiler

\section{INTRODUCTION}

The goal of poultry abattoirs is to reduce meat and carcass defects and optimize bleed out of poultry which lead to improve the quality of meat during storage

Corresponding author: Eman Shukry

E-mail address: emanshukry81@gmail.com

Present address: Department of Food Hygiene, Animal Health Research Institute, Mansoura lab
(Schutt-Abraham, 1995). Electrical Stunning systems for poultry were initially developed to immobilize the bird long enough to allow physical manipulation of the bird, and to reduce carcass damage due to unconscious, physical activity such as wing flapping and violent muscular contraction during bleeding. (Nakyinsig et al., 2013). Water bath stunning is applied to relax neck muscles and contract wing muscles for easy fixation of the head. It 
prevents excessive struggling and wing flapping during bleed -out, facilitate rapid bleeding and relax or loosens feathers. This method of electrical Stunning is quick and the system required on line operation is relatively inexpensive. The birds pass through the stunner cabinet in continuous procession which is vertically adjusted and usually set at height that allow the heads of birds to be submerged in the bottom of the water bath tank. When a voltage is applied between submerged electrode and the earth (ground), the current flows through the immersed chickens in the cabinet to complete the circuit (Mortada, 2003).

Due to the importance of humane slaughter and meat quality issues, slaughter technology (live bird handling, stunning, slaughter and bleeding) has received considerable research interest (Biligili, 1999, Fletcher, 1999, 2000). So according to Heath et al. (1984) more than $92 \%$ of all poultry plants in the US subjected poultry electrical stunning and $66 \%$ of these plants use low voltage. Biligili (1999) reported that recent advances in electrical stunning have focused on extending stunning time and lowering stunning voltage. Biligili (1992) stated that the electrical stunning using water bath stunner is the most common method to stun poultry. Stunning and slaughtering techniques can have a major effect on the incidence of a number of carcass defects, such as hemorrhages in muscle tissue, red wing tips and broken bones. Kranen et al. (1998) reported that muscle tissue hemorrhages can be caused by pre-slaughter electrical stunning especially in the breast muscle which consider a major problem in the sale of broiler carcass or parts, susceptibility of muscle hemorrhages caused by electrical stunning depends on the individual impedance of the birds genetic and environmental factors such as cold weather conditions intensify this problem.

Red wing tips consider one of the most defects which lead to loss of salable yield of whole carcasses especially if the wings requiring trimming. Gregory (1989) reported that the incidence of the defect (red wing tips) was associated with the incidence of wing flapping during the shacking process at slaughter house. While (Heath, 1984) stated that these defects due to blamed rupture of blood vessels during plucking process on other hands, found that stunning at $200 \mathrm{~V}$ resulted in significantly more red wing tips and tails than broilers stunned at $75 \mathrm{~V}$ and this indicate low voltage stunning can reduce these defects.

Although broken bones in broiler carcasses is not common problem but considers one of common defects that lead to down grading of carcasses and usually that is due to physical damage in life birds during plucking or forced movement after slaughter without stunning. (Gregory and Wilkins, 1989).

The Islamic method (traditional halal method) which is widely used in western countries where there is global population of Muslims and their interest in adhering to their religious doctrines requires the use of sharp knife which according prophet Muhammad (Peace be upon him) relive the animal of any suffering (Sahih Muslim). Maximum daring of blood is required. In the Holy Quran, blood consumption has been forbidden by Muslims. (Ali and Abdallah, 2011) and (Farouk 2013).

Blood considers to be an excellent medium for growth of bacteria due to high nutritive value, its temperature, $\mathrm{pH}$ and relative humidity. The amount of blood bled by the animal or bird depends on the slaughter method used. In addition to blood components, especially hemoglobin are powerful promoters of lipid oxidation (Alvarado and Sams, 2000).

Oxidation is a chemical reaction produce free radicals that damage the cells and manifest as adverse biological effects. Superoxide dismutase (SOD), glutathione peroxidase (GPX) and Catalase (CAT) are the main antioxidant enzymes in the body 
contributing to the antioxidant activity. Oxidative stress can cause chicken meat with unpleasant odors and loss in flavor, texture consistency, appearance and nutritional value (Altan et al., 2003).

The objective of the following study is to determine the effect of low electrical stunning voltage on sensory evaluation, quality indicators $(\mathrm{pH}, \mathrm{TVB}$, total bacterial counts), chemical composition and antioxidants enzymes.

\section{MATERIALS AND METHODS}

\section{Birds}

Two hundred of apparently healthy birds (they did not show any signs of diseases in anti-mortem inspection). 37 old day, weight $2 \mathrm{k}$. Ross 208, from one flock (hatched and rose at the same environmental and nutritional conditions). Feeds were withdrawn from broiler before slaughter with $8 \mathrm{hr}$ meanwhile drinking water were available till caught.

\section{Processing:}

This study was carried out at commercial processing plant with capacity 4000 birds per hour, birds were divided into 2 groups each one 100 birds.

$1^{\text {st }}$ one $\rightarrow$ slaughtered without stunning. $2^{\text {nd }}$ group $\rightarrow$ sunned in water bath stunner.

(Linco, Lind holst water- bath stunner) at 40 voltage. The time between hanging and stunning was $30 \mathrm{sec}$, stunning duration about 10 seconds.
Immediately after hanging $1^{\text {st }}$ group or $2^{\text {nd }}$ group, were slaughtered by severing both carotid artery and jugular vein using a sharp knife, manually in compliance with Islamic rituals. Slaughtered bird were allowed to bleed for $180 \mathrm{~s}$ and reweighed to determine the percentage of blood loss. The carcasses were then scalded for $2 \mathrm{~min}$. at $56^{\circ} \mathrm{C}$ in thermostatically controlled scalding tank (Linco Scalder) equipped with circulating pump discharging the water at the top of the tank and over the immersed birds. Plucking was done using a mechanical plucker (Linco tunnel picker) for $45 \mathrm{sec}$. The carcasses were eviscerated using an automatic viscera removal apparatus. Chilling occur in air counter current chiller for $45 \mathrm{~min}$.

\section{Sampling:- \\ Sensory evaluation}

Carcasses were evaluated for acceptability according to Land and Shepherd (1988) using-a9- point structured hedonic scale by semi trained panel of 5 judge's regarding color, odor, texture and appearance with numerical scores and acceptance.

Meat quality (carcasses damage):- carcass damage from each treatment was measured according to the method of Contreras and Beraquet, (2001). Carcass damage was measured with a transplastic cord that had a1x1 $\mathrm{mm}$ square. The score of carcass damage was calculated according the standard scoring of carcass damage as shown in the following table.

Table 1: Standard scoring of carcass damage.

\begin{tabular}{ccc}
\hline leg's pectorals major and minor & Wing & Score \\
\hline area $\leq 0.04$ & $\mathbf{a . e .} \leq \mathbf{0 . 0 8 \mathbf { ~ c m } ^ { 2 }}$ & 5 \\
\hline $0.04-0.16$ & $0.08-0.32$ & 4 \\
\hline $0.16-0.36$ & $0.32-0.72$ & 3 \\
\hline $0.36-0.64$ & $0.72-1.28$ & 2 \\
\hline $0.64-1$ & $1.28-2$ & 1 \\
\hline$>1$ & $2 \geq$ & 0 \\
\hline
\end{tabular}

*Broken bones, red wing tips, wing bleeding spots and breast bleeding spots are calculated as percent and grade of damage.

(Any carcasses have defect are graded as $2^{\text {nd }}$ grade. (Grade B) and considered as manufacturing defects). 
Whole carcasses were examined for carcass defects:- Red wing tips, Broken bones, Breast blood spots, Wing bleeding spots. Carcasses defect were evaluated immediately after evisceration and before chilling according to Ali et al. (1996).

\section{Quality indicators:}

Samples for Bacteriological examination:

About 20 slaughtered carcasses from each group were randomly chosen for samples. From each carcass, 25gm including skin and muscles from breast and thigh were homogenized in $215 \mathrm{ml}$ sterile peptone water $0.1 \%$. Serial dilution was prepared. $0.1 \mathrm{ml}$ of each dilution was transferred into standard plate count agar and incubated a $37^{\circ} \mathrm{C}$ for $48 \mathrm{hr}$.

Total aerobic plate counts were performed according to ICMSF (1978):-

Twenty five grams of skin and meat from breast, thigh of each sample cooled aseptically were homogenized in $225 \mathrm{ml}$ of $0.1 \%$ sterile peptone water solution for 2 minutes in a sterile blender container at high speed. To provide a homogenize of 1/10 dilution. Serial dilution are required, were prepared. $0.1 \mathrm{ml}$ of each dilution was transferred into standard plate count agar (for each conc. 2 peptone dish) and incubate at $37^{\circ} \mathrm{c} / 48 \mathrm{hr}$. Plates with $30-300$ colonies were selected and counted. The mean count was calculated and recorded per 1 gram meat.
pH:- The $\mathrm{pH}$ of carcasses muscle immediately after chilling of 20 carcasses from each group was determined using calibrated $\mathrm{pH}$ meter (FE-20) MettlerToledo- Instruments Co., Ltd., Zurich Switzerland). Each muscle sample was measured in Triplicate with a spear- type electrode at bone side (cranial end) of the pectorals major.

\section{Chemical Composition:}

At carcass dissection, breast and thigh muscles were vacuum packaged and immediately frozen at $\left(-20^{\circ} \mathrm{c}\right)$ pending analysis. The AOAC methods (1984) were used to assess moisture content by using the hot air oven drying method. The protein content was analyzed by Kjeldahl method while fat content was analyzed by Soxhlet method. Total volatile base (TVB) also will be analyzed according to (AOAC,1990) and the results were expressed as percentage on a fresh matter basis.

\section{Antioxidant parameters:}

After the chicks were slaughtered muscle tissue were separated then washed with normal saline for determination of superoxide dismutase (SOD) activity according to Nishikimi et al. (1972), reduced glutathione (GSH) according to Anderson (1985), Catalase (CAT) according to Aebi (1984) and Malondialdhide MDA content according to Satoh (1978).

\section{RESULTS}

Table 2: Sensory evaluation

\begin{tabular}{cccccc}
\hline $\begin{array}{c}\text { Type and (No.) of } \\
\text { sample }\end{array}$ & Color & Texture & Appearance & Odour & Acceptance \\
\hline $\begin{array}{c}\text { Non stunned } \\
(100)\end{array}$ & $7^{\mathrm{a} \pm 0.577}$ & $6^{\mathrm{a}} \pm 0.667$ & $5^{\mathrm{a}} \pm 0.577$ & $7^{\mathrm{a}} \pm 0.00$ & $6^{\mathrm{a}} \pm 0.577$ \\
\hline $\begin{array}{c}\text { Stunned } \\
\text { Carcasses (100) }\end{array}$ & $8^{\mathrm{b} \pm 0.577}$ & $8^{\mathrm{b}} \pm 0.00$ & $7^{\mathrm{b}} \pm 0.33$ & $7^{\mathrm{a}} \pm 0.00$ & $7.5^{\mathrm{b}} \pm 0.33$ \\
\hline
\end{tabular}

Values are expressed as means \pm standard error of the mean

$a, b$ means with different subscripts within columns are significantly different $(p<0.05)$ 
Table 3: Effect of stunning on defects of broiler carcasses.

\begin{tabular}{|c|c|c|c|c|c|c|c|c|c|c|c|c|}
\hline \multirow{3}{*}{$\begin{array}{c}\text { Type and } \\
\text { (No.) of } \\
\text { carcass }\end{array}$} & \multirow{2}{*}{\multicolumn{2}{|c|}{ Brocken bone }} & \multirow{2}{*}{\multicolumn{2}{|c|}{$\begin{array}{c}\text { Red Wing } \\
\text { tips }\end{array}$}} & \multirow{2}{*}{\multicolumn{2}{|c|}{$\begin{array}{c}\text { Wing } \\
\text { bleeding spots }\end{array}$}} & \multirow{2}{*}{\multicolumn{2}{|c|}{$\begin{array}{c}\text { Breast } \\
\text { bleeding } \\
\text { spots }\end{array}$}} & \multicolumn{4}{|c|}{ Grading } \\
\hline & & & & & & & & & \multicolumn{2}{|l|}{$\mathbf{A}$} & \multicolumn{2}{|l|}{ B } \\
\hline & No & $\%$ & No & $\%$ & No & $\%$ & No & $\%$ & No & $\%$ & No & $\%$ \\
\hline $\begin{array}{c}\text { Non } \\
\text { stunned } \\
(\mathbf{1 0 0})\end{array}$ & $5^{\mathrm{a}} \pm 0.33$ & 5 & $4^{\mathrm{a}} \pm 0.33$ & 4 & $4^{\mathrm{a}} \pm 0.577$ & 4 & $2^{\mathrm{a}} \pm 0.00$ & 2 & $85^{\mathrm{a}} \pm 0.58$ & 85 & $15^{\mathrm{a}} \pm 0.577$ & 15 \\
\hline $\begin{array}{c}\text { Stunned } \\
(\mathbf{1 0 0})\end{array}$ & $1^{\mathrm{b}} \pm 0.577$ & 1 & $0^{\mathrm{b}} \pm 0.00$ & 0 & $1^{\mathrm{b}} \pm 0.00$ & 1 & $6^{\mathrm{b}} \pm 0.57$ & 6 & $92^{\mathrm{b}} \pm 0.57$ & 92 & $8^{\mathrm{b}} \pm 0.333$ & 8 \\
\hline
\end{tabular}

Values are expressed as means \pm standard error of the mean

$a, b$ means with different subscripts within columns are significantly different $(p<0.05)$

Table 4: Effect of electrical stunning on quality indicators:

\begin{tabular}{cccc}
\hline Type and (No.)of carcass & Total bacterial count & $\mathrm{pH}$ & TVB \\
\hline Non stunned (20) & $4.3 \times 10^{5} \pm 1.07 \times 10^{5}$ & $5.25 \pm 0.58$ & $13.06 \pm 2.4$ \\
\hline Stunned (20) & $3.3 \times 10^{5} \pm 3.3 \times 10^{5}$ & $5.31 \pm 0.54$ & $13.77 \pm 0.77$ \\
\hline
\end{tabular}

Table 5: Effect of stunning on chemical quality of broiler carcasses.

\begin{tabular}{ccccc}
\hline $\begin{array}{c}\text { Type and (No.) of } \\
\text { carcass samples }\end{array}$ & Moistures & Protein & Lipids & Ash \\
\hline Non stunned (20) & $70.98^{\mathrm{a}} \pm 1.99$ & $15.88^{\mathrm{a}} \pm 2.02$ & $10.73^{\mathrm{a}} \pm 0.072$ & $01.52^{\mathrm{a}} \pm 1.02$ \\
\hline Stunned (20) & $71.47^{\mathrm{a}} \pm 1.67$ & $15.21^{\mathrm{a}} \pm 1.78$ & $11.3^{\mathrm{a}} \pm 0.23$ & $1.36^{\mathrm{a}} \pm 0.046$ \\
\hline
\end{tabular}

Values are expressed as means \pm standard error of the mean

$a, b$ means with different subscripts within columns are significantly different $(p<0.05)$

Table 6: Effect of electrical stunning on anti oxidants.

\begin{tabular}{ccccccc}
\hline $\begin{array}{c}\text { Type and (No.) } \\
\text { of samples }\end{array}$ & $\begin{array}{c}\text { Oxidized } \\
\text { GSH } \\
\text { ng/g tissue }\end{array}$ & $\begin{array}{c}\text { Reduced } \\
\text { GSH } \\
\text { ng/g tissue }\end{array}$ & $\begin{array}{c}\text { Total GSH } \\
\text { ng/g tissue }\end{array}$ & $\begin{array}{c}\text { SOD } \\
\text { ng/g tissue }\end{array}$ & $\begin{array}{c}\text { CAT } \\
\text { U/g tissue }\end{array}$ & $\begin{array}{c}\text { MDA } \\
\text { (M mol/g } \\
\text { tissue) }\end{array}$ \\
\hline $\begin{array}{c}\text { Non stunned } \\
\text { carcasses (100) }\end{array}$ & $0.35^{\mathrm{a}} \pm 0.07$ & $5.66^{\mathrm{a}} \pm 0.45$ & $6.01^{\mathrm{a}} \pm 0.49$ & $13.85^{\mathrm{a}} \pm 0.68$ & $14.56^{\mathrm{a}} \pm 0.33$ & $37.68^{\mathrm{a} \pm 2.56}$ \\
\hline $\begin{array}{c}\text { stunned } \\
\text { carcasses (100) }\end{array}$ & $0.29^{\mathrm{a}} \pm 0.03$ & $6.55^{\mathrm{b}} \pm 0.38$ & $6.84^{\mathrm{a}} \pm 0.45$ & $15.79^{\mathrm{b}} \pm 0.76$ & $16.87^{\mathrm{b}} \pm 0.96$ & $36.92^{\mathrm{a}} \pm 0.95$ \\
\hline
\end{tabular}

Values are expressed as means \pm standard error of the mean $a, b$ means with different subscripts within columns are significantly different $(p<0.05)$ GSH (glutathione) SOD (Super oxide dismutase)

MDA (monaldehide) CAT (Catalase) 


\section{DISCUSSION}

As the poultry industry has become more involved in further processing, the importance of strict process control process to maintain consistent meat quality is increasing. At the same time, quality characteristics that affect consumer acceptability are changing. Instead of emphasizing carcass characteristics, such as absence of defects and skin color, new emphasis is being placed on functional characteristics of the meat, such as texture, moisture binding, and color. These latter quality characteristics are directly affected by many factors, one of these factors electrical stunning (Yong and lyon, 1997 and Wilkins et al., 1998).

The data present in Table (2) showed that sensory evaluation of stunned and non stunned poultry carcasses color, texture, appearance, odor, and general acceptance were numerically examined and they were $7,6,5,7,6$ respectively in non stunned carcasses meanwhile in stunned carcasses they were $8,8,7,7$ and 7.5 , respectively, for the same sensory characters respectively. These results declared that there was low effect of low voltage electrical stunning on sensory evaluation of poultry carcasses specially color and general acceptance. Other studies also have shown that different electrical stunning systems did not affect color of chicken meat (Craig and Fletcher, 1997, Northcutt et al., 1998, and Craig et al.,1999).

In contrast, Dickens and Shackelford (1988) indicated that in United State of American (U. S. A.), low current (10 to 45) electrical stunning was primarily used to decrease feather release force which will increase general acceptance of produced poultry meat. The statistical analysis declared that there was a significant differences between non- stunned group and stunned one in color, texture, appearance and acceptance and there is no significant differences in odour.
Table (3) showed that the effect of stunning on incidence of broken bones, red wing tips, wing bleeding spots, breast bleeding spots and grading A or B (second grade). These defects were defined as manufacturing defect which have great economic importance as there is a great decrease in price between grade $A$ and grade $\mathrm{B}$ carcasses. The incidence of broken bones, red wing tips, wing bleeding spots, breast bleeding spots and grading $\mathrm{A}$ and $\mathrm{B}$ in non stunned carcasses were $5,4,4,2,85$ and 15 respectively while in stunned carcasses were 1,0,1,6,92 and 8 respectively for the same defects. It is clear that the broken bone were decreased from 5 in non stunned group to 1 in stunned group. This is due to the ability of low voltage electrical stunning to reduce motility of slaughtered bird comparing with non stunned bird which suffered great physical damage due to forced movement after slaughter (Gregory and wilkins, 1989).

The incidence of red wing tips were reduced from 4 in non stunned carcasses to 0 in stunned carcasses (Mortada, 2003). The wing bleeding spots also were reduced from 4 in non stunned carcasses to 1 in stunned one.

On other side, the breast bleeding spots were increased from 2 in non stunned carcasses to 6 in stunned one. Concerning grading all carcasses have defects were grading B and they were 15 in non stunned carcasses which cause great economic losses than in non stunned carcasses were the grad B were 8. The statistical analysis declared that there was significant differences between non- stunned group and stunned one in broken bone, red wing tips, wing bleeding spots, breast bleeding spots and grading.

The data present in Table (4) showed that the mean of total aerobic counts was $4.30 \times 10^{5}$ in non stunned carcasses with standard error of $1.02 \times 10^{5}$ Mean while in stunned carcasses the mean of Total aerobic counts were $3.3 \times 10^{5}$ with standard error 
$1.01 \times 10^{5}$. This increase in total aerobic count in stunned carcasses than that in non stunned carcasses agreed with that reported by Addeen et al. (2014) and Ali et al. (2007) who found lower count of bacteria in chicken meat obtained from chicken slaughtered without stunning. Sabow et al. (2015) attributed that these may be due to the faster postmortem $\mathrm{pH}$ decline of meat from electrically stunned animal. Nakyinsige et al. (2014) reported increased total aerobic plate count in meat of stunned animal due to increased amount of blood left within the carcass after bleeding. This blood residue favored multiplication of microorganisms. Table (4) also recorded the results of $\mathrm{pH}$ and TVN. They were 5.25 \pm 0.58 and $13.06 \pm 2.40$ respectively in non stunned carcasses while in stunned group, $\mathrm{pH}$ and TVN were 5.31 \pm 0.54 and $13.77 \pm 0.77$ respectively. From these results the water bath electrical stunning treatment before slaughtering were increase $\mathrm{PH}$ from $5.25 \pm 0.58$ to $5.31 \pm 0.54$ these results agree with these detected by (Gezgin and Karakaya 2016). Murphy et al. (1988), Thomas et al. (1986), Alvarado and Sams (2000) explained these increase in $\mathrm{pH}$ may be due to limited glycolytic activity in the muscles during the slaughter process.

Data present in Table (5) showed that the effect of electrical stunning on chemical composition of slaughtered carcasses as the Moisture, fat, proteins, Ash, PH and TVN. The chemical analysis of non stunned group were $70.98 \pm 1.99,15.88 \pm 2.02,10.73 \pm 072$, $1.52 \pm 1.02$, respectively, meanwhile in stunned group the chemical analysis were $71.47 \pm 1.67, \quad 15.21 \pm 1.78, \quad 11,3 \pm 0.23$, $1.36 \pm 0.046$, respectively. It is clear that there is no detectable effect on chemical composition of produced poultry meat.

In our results, table (6) showed the effect of low voltage water bath electrical stunning on antioxidant parameters including oxidized glutathione, reduced glutathione, total glutathione (GSH), super oxide dismutase (SOD), catalase (CAT) and monaldhide (MDA), light increase (insignificant increase) in GSH, SOD and CAT enzymes and a decrease in MDA concentration which may lead to improve first stage of lipid oxidation than in nonsunned bird. Addeen et al. (2014) and Gabig and Babior (1981) explained these results apart from hemoglobin, blood is also capable of generating SOD and other enzymes which are known to enhance the lipid oxidation which involved in off flavor, formation of rancid odors and discoloration.

\section{CONCLUSION}

The present results declared that lower voltage water bath electrical stunning before slaughtering in broiler carcasses in compare with non-stunned slaughtered broiler carcasses have some advantages as improve carcasses quality due to decrease manufacture defecates as red wing, brocken bones and wing bleeding spots which has great economic importance although the breast bleeding spots were increased. Also it increases the overall acceptance of the slaughtered broiler carcasses. On the other hand, it have some disadvantage due to increase microbial load and $\mathrm{pH}$ in addition to somewhat increase in antioxidant enzyme which may initiate lipid oxidation, with no effect on chemical structure of broiler meat.

\section{REFERENCES}

Addeen, A.; Benjakul, S.; Wattanachant, S. and Maqsood, S. (2014): Effect of Islamic Slaughtering on chemical compositions and post-mortem quality changes of broiler chicken meat. Int Food Res J 21: 897-907.

Aebi, H. (1984): "catalase in vitro". Methods enzymol. 105: 121-126.

Ali, A. and Abdalla, H. (2011): Effect of slaughtering method on the keeping quality of broiler chickens meat. Egypt poultry Sci. 31: 727-736. 
Ali, A.; Lawson, M.; Tauson, A.; Jesen, J. and Chwalibog, A. (2007): Influence of electrical stunning voltages on bleed out and carcass quality in slaughtered broiler chickens. Arch Geflugelkd 71: 35-40.

Ali, A.S.A.; Fris Jensen, J. and Asknov Jensen, J. (1996): Effect of differen $t$ electrical stunning voltages on blood loss, carcass quality and breast muscle muscle PH. Archiv for Gefluselkunde 3, 126-131.

Altan, O.; Pabuccuoglu, A.; Altan, A.; Konyalioglu, $S$. and Bayraktar, $H$. (2003): Effect of heat stress on oxidative stress, lipid peroxidation and some stress parameters in broilers. Br. Poult. Sci(44): 45-50.

Alvarado, C.Z. and Sams, A.R. (2000): Rigor mortis development in turkey breast muscle and the effect of electrical stunning poultry Science 79(11), 1694-1698.

Anderson, M.E. (1985): Determination of glutathione and glutathione disulphide in biological samples. Method Enzymol. 113: 548-551.

AOAC Association of Official Analysis Chemists (1984): Official Methods of analysis $12^{\mathrm{TH}}$ ed. Washington, DC., USA.

AOAC Association of Official Analysis Chemists (1990): Official Methods of analysis $3^{\text {rd }}$ ed., Washington, DC., USA.

Biligili, S.F. (1992): Electrical stunning of broilers- Basic concepts and carcass quality implications: A review. $J$. Appl. Poult. Res. 1: 135-146.

Biligili, S.F. (1999): Recent Advances in electrical stunning poultry Sci. 78: 282-286.

Contreras, C.C. and Beraquet, N.J. (2001): Electrical stunning, hot boning, and quality of chicken breast meat. Poultry Sci. 80: 501-507.

Craig, E.W. and Fletcher, D.L. (1997): A comparison of high current and low voltage electrical stunning systems on broiler breast rigor development and meat quality poultry science 76 (8), 1178-1181.

Craig, E.W.; Fletcher, D.L. and Papinaho, P.A. (1999): The effects of antemortem electrical stunning and postmortem electrical stimulation on biochemical and textural properties breast meat. Poult. Sci 78: 490-494.

Dickens, J.A. and Shackelford, A.D. (1988): Feather releasing forces related to stunning, scalding time and temperature. Poultry Sci. 67: 10691074.

Farouk, M.M. (2013): Advances in the industrial production of halal and Koshar red meat. Meat Sci (95): 805820.

Fletcher, D.L. (1999): Slaughter Technology. Poultry Sci.78: 277-281.

Fletcher, D.L. (2000): Stunning of poultry .proceedings of XX I world poultry congress, Montreal, Canada: 3-.13.

Gabig, T.G.; and Babior, B.M. (1981): The killing of pathogens by phagocytes. Annu Rev Med 32: 313-326. PMID: 7013670.

Gezgin, T. and KaraKaya, M. (2016): The effects of electrical water bath stunning on meat quality of broiler produced in accordance with Turkish slaughter procedures. Jour. poultry Res. 13(1): 22-26.

Gregory, N.G. and Wilkins, L.J. (1989): Effect of stunning current on carcass quality in chickens. Vet. Rec. 124: 530-532.

Gregory, N.G. (1989): Stunning and slaughter. Pages 31-36 in: Poultry processing, G.C. Mead ed. Elsevier Applied Sci., London., UK.

Heath, G.B.S. (1984): The slaughter of broiler chickens. World Poultry Sci. J. 40(2): 151-159.

ICMSF (1978): International commission on microbes specification. Microorganism in Foods. Sampling for microbiological analysis.

Kranen, R.W.; Veerkamp, C.H.; Lambooy, E.; Vankuppevett, T.H. and Veerkamp, J.H. (1998): The effect of 
thermal preslaughter stress on the susceptibility of broiler chickens difference with respect to growth rate, age at slaughter, blood parameter ans ascites. Poultry Sci., 77(5): 737-744.

Land, D.G. and Shepherd, R. (1988): Scaling and Ranking methods, J.R.Ed. Sensory analysis of food. Elsevier applied Sci.

Mortada, A.M.F. (2003): Effect of electrical stunning on broiler carcasses quality. B.Sc. faculty of animal production; University of Khartoum.

Murphy, B.D.; Hasiak; R.J. and Sebranek, J.G. (1988): Effect of ante mortem electrical stunning on functional properties of Turkey muscle. Poultry Sci. 67 (7), 1062-1068.

Nakyinsige, K.; Fatimah, A.; Aghwan, ZA.; Zulkifli, Goh, YM. and Sazili, AQ. (2014): Bleeding efficiency and meat oxidative stability and microbiological quality of New Zealand White rabbits subjected to halal slaughter without stunning and gas stun-killing. Asian-Australas J Anim Sci 27: 406-413.

Nakyinsige, K.; Che Man, Y.BH.; Aghwan, Z.A; Zulkifli, I.; Goh, Y.M. and Abu Bakar, F.C. (2013): Stunning and animal welfare from Islamic and scientific prespective. Meat Sci 95: 352-361.

Nishikimi, M.; Rao, N.A. and Yogi, K. (1972): The occurance of super oxide anion in the reaction of reduced phenazinemethosulfate and molecular oxygen. Biochemical and Biophysical Research. Common, 46: 849-854.

Northcutt, J.K.; Buhr, R.J. and Young, L.L. (1998): Influence of preslaughter stunning on turkey breast muscle quality. poult. Sci. 77; 487-492.

Sabow, A.B.; Sazili, A.Q.; Zulkifli, I.; Goh, Y.M.; Abo Kadir, M.Z.A. and Abdull, N.R. (2015): A comparison of bleeding efficiency, microbiological quality and lipid oxidation in goats subjected to conscious halal slaughter and slaughter following minimal anesthesia. Meat Sci 104: 78-84.

Satoh, K. (1978): "Serum lipid peroxide in cerebrovascular disorders determined by a new colorimetric method. Clin. Chim. Acta. 90:37.

Schutt-Abraham, I. (1995): Stunning methods for poultry: influence on birds' welfare and prospects for future EC regulations. Pages 333-344 in: Poultry Meat Quality, R.C.Briz, ed. Proceedings of the XII European Symposium on the Quality of poultry Meat, Zaragoza, Spain.

Thomas, J.E.; Lyon, C.E.; Hamm, D.; Dickens, J.A.; Fletcher, D.L. Shackelford, A.D. (1986): Effects of electrical stunning and hot deboning on broiler breast meat quality. Poultry Sci.65(9), 1715-1719.

Wilkins, L.J.; Gregory, S.N. Wotton, S.B.; Parkman, I.D. (1998): effectiveness of electrical stunning applied using a variety of wave-frequency combination and consequences for carcass quality in broiler chickens. Br. Poultry SCi 39: 511-518.

Yong, L.L. and Lyon, C.E. (1997): Effect of calcium marination on biochemical and textural properties of peri-rigor chicken breast meat. Poultry Sci. 67: 197-201. 


\section{تاثير التدويخ الكهربائى على جودة ذبائح بداري التسمين}

\section{صالح شفيق محمد ، ايمان شكري جاد ، زغلول احمد عبل المنعم خضر}

E-mail: emanshukry81@gmail.com Assiut University web-site: www.aun.edu.eg

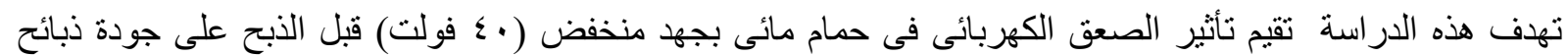

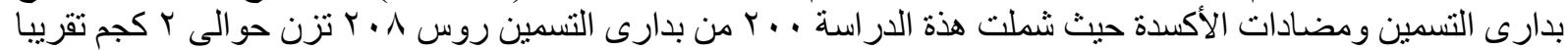

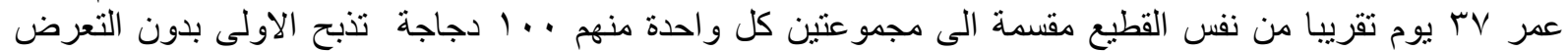

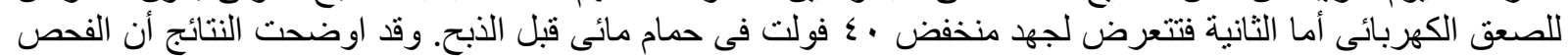

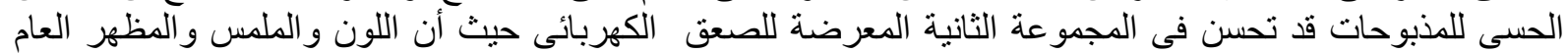

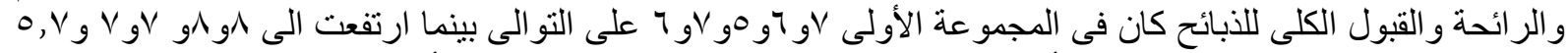

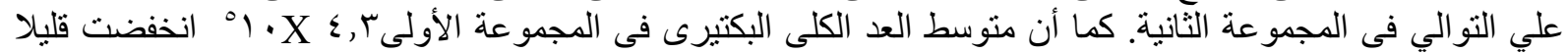

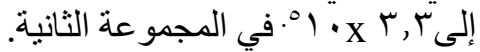

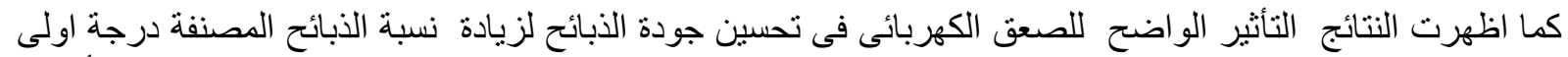

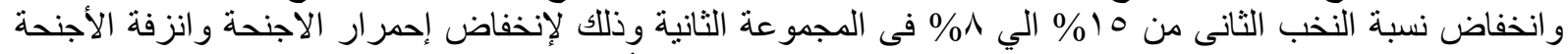

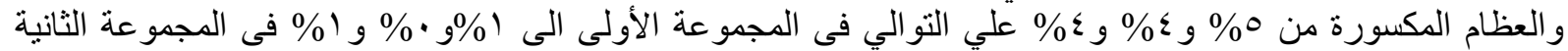

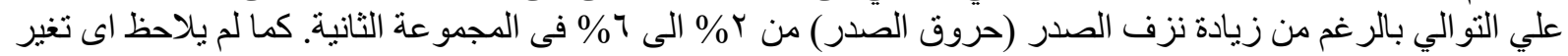

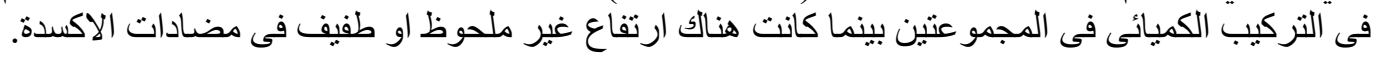

ومما سبق يتضح لنا أن التدويخ الكهربائي قبل ذبح بداري التسمين يؤدي الي زيادة جودة الذبائح نتيجة لتقليل عيوب المنتج مثل العظام و الأجنحة المكسورة ولا لاؤثر في التركيب الكيميائي للذبائح. 